\title{
REVIEWING A NOTARY ETHICS BASED ON ETHICAL CODE AS A NOTARY PROFESSION
}

\author{
Hafidzakariya, Yuni Purnama Sari, Desty Prabandari, \\ Widha Rahmawati Budiatmaja \\ Faculty of Law, Universitas Islam Batik (UNIBA), Surakarta \\ Email : widhabudiatmaja@yahoo.com
}

\begin{abstract}
This paper aimed to find out the responsibilities and sanctions of a notary when a notary violates the existing ethics code.The various rules in the notary profession code of ethics will be attributed to the notary's behavior, so that in carrying out the duties there is a responsibility that must be enforced and If it contradicts with the ethics code, it will get sanction in accordance with the enactment of the Notary's Office Law. Because the role of notary in society is important to determine the land deed in Indonesia, we need to understand how the notary in enforcing their ethics as notary profession. The Notary is expected to be neutral, so if placed in one of the three state agencies Judiciary, Executive, and Legislative, the Notary is no longer considered neutral. With the neutral position, notary is expected to provide legal counseling for a legal action by a notaryat the request of client. In the case of taking legal action for client, the notary also may not take side the client, because the duty of a notary is to prevent the occurrence of problems.

Keyword : Responsibility Sanction, Notary Profession
\end{abstract}

\section{A. INTRODUCTION}

Ethics in law profession is very important Every individual, eveyone, and whatever the profession, it needs rule to organize the good or bad of human actions, so that they can distinguish the good or bad, the do or don't, even though they can make it happen. Morality is principles and moral rules in social life. So it is with the legal profession. Legal professions are required to always pay attention to ethics and morals while performing their duties, because as the legal profession is very susceptible with various problems.

The meaning of ethics etymologically comes from Greek "Ethos", that means character of decency or custom. Ethics can be interpreted as a collection of principles or moral value, moral philosophy, and the most 
important as moral values and norms which become a gidance for human in organizing their behaviour.

While the definition of the profession in etymology takes from a

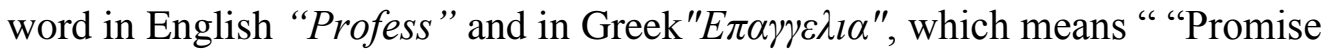
to fulfill the obligation to perform a specific task on a regular/permanent basis". A profession can also be defined as a someone's position that the profession is not commercial, mechanic, agriculture, and so on.According to Muhammad "Imaduddin Abdulrahim" in his writing entitled "Profesionalisme In Islam" on suggest that: The Profesionalism usually understood as a quality that every good executive must have. There are several features of a profession, That is, first, they have high skills in a field also can usecan use certain equipment required in the execution of the task. Second, have knowledge and experience and intelligence in analyzing a problem, and sensitive in reading situations, fast and precise and careful in taking a decision. Third, they have attitude oriented to the future, so they have the ability to anticipate the development of the environment that lies ahead. Fourth, they have independent attitude based on belief in personal ability, as well as open listening and appreciate the opinions of others (Suhrawardi K. Lubis, 2016: 10).

Professional ethics is an ethical attitude as an integral part of the attitude of life in living the life as a carrier profession. Only the caretaker of the profession can know on whether the behavior in carrying out the profession meets the demands of his professional ethics or not.

In the legal field there are several legal professions, one of them is a notary profession. Notary is one of the noble legal profession. Whythe profession as a notary can be a noble profession?Because notary profession is very closely connected with humanity. A notarized deed may become the legal basis in dalam the status of one's property, rights, and duties. If there is mistake in the deed made by the notary, it will causerevocation of one's rights so it cause someone burdenend by the responsibility. Therefore, the notary in performing his duties must comply with the regulations contained within 
Notary Public Regulation. According to Regulation Number 30 of 2004 on notary profession clause 1 mentioned that,"A Notary is a general official who authorized on making authentic deed and other authority as referred to this regulation". This notary profession is included in the realm of civil law.

Notary Public Regulation is an institution created by the state.Notary Public Regulationhas used jointly notary institution as position and profession.Notary Public Regulation clause 1 verse 1 mentioned that, "The Notary Public Regulationdetermines that a notary is a public official authorized to make authentic deeds and other powers". notary position held or its presence is desired by the rule of law to help and serve the public who need authentic written evidenceregarding circumstances, events, or legal acts. Notaries are appointed by the state authorities and given trust and recognition in providing service for public interest.

\section{B. PROBLEMS}

In this journal will be discussed, How the responsibility of notary in running profession based on existing code of ethics? And What is a notary sanction against the realization of professionalism as a notary profession? The purpose of this journal is to know and understand the responsibilty of code of ethics inrunning a profession as a notary also to know the sanction of code of ethics towards the realization of notaryprofessionalism.

\section{RESEARCH METHODS}

This research is a type of normative research. The normative research or research method of literature law is a method or way used in law research by observing the existing literature material, by using various secondary data such as regulations, law theory, and opinion of the scholars. In this case, the research is related with profession of law aspect with the problems of notary behaviour as notary code of ethics.

\section{RESEARCH RESULT AND DISCUSSION}




\section{The responsibility of a notary in running the profession based on the}

existing code of ethics.

In performing his duties a notary they have to cling to code of ethics of notary profession.Notary Code of Ethics is a moral rule whics is determined byAssociation of Indonesian Notary Bond based on Decision Congress of the Society and/or determined and arranged in regulations which arrange about that and applicable and must obeyed by every and all of the member of association and all of the people who carries out duties and positions as a notary.

As a public official, a notary must have several conditions:

1. Spirited Pancasila;

2. Obey the law, oath of office, notary code of ethics;

3. Good in Bahasa Indonesia.

As A Notary Profession :

1. Have the ethics as a notary;

2. Take part in the national development of law field;

3. Uphold the honor and dignity.

The authority of a notary under the Regulation of Notary Clause15:

1. Create an authentic deed of all deeds, covenants, and statuteswhich is required by the rtegulations and/or which is desired by the interested parties, to be expressed in an authentic deed, guarantee the date of making the deed, save deed, give grosse, copy and quotation deed, all of them during the making of the deed is not assigned or excluded to another officialor person as defined by the regulations.

2. Authorize signaturesand specify the date of making the letter under the hand by registering in a special book (legal).

In Chapter III Clause 3, The Notary code of ethics, arranged about the responsibily and the duty which should be run by notary and others who manage notary position :

a. Have moral, morals, and a good personality 
b. Respect and uphold the dignity of a notary

c. Maintain and defend the honor of the society

d. Be honest, independent, impartial, full of responsibility, based on legislation and ishe of oath of office of notary

e. Improving the science that has been owned, not limited to the science of law and notary.

f. Prioritize the devotion to the interests of society and the state.

g. Providing services for making deeds and services for people who can not afford without collecting honorarium.

h. Setting an office in a place of position.

i. Installed 1 nameplate in the office environment $(100 \mathrm{~cm} \times 40 \mathrm{~cm} /$ $150 \mathrm{~cm} \times 60 \mathrm{~cm} / 200 \mathrm{~cm} \times 80 \mathrm{~cm})$, which contains : Full name and a legitimate title, Date and number of the last assignation letter as a notary, place of position, office address and telephone / fax number. The base of Name board is in white, and the letter is in black.

j. Attend in every activity organized by association

k. Pay the money in an orderly manner

1. Pay the mourning money to help the heirs of friends who died.

m. Comply with all honorarium conditions set by associations.

n. Running a notary

o. Creating an atmosphere of kinship and togetherness in carrying out daily tasks

p. Treat clients well, not distinguish economic status

q. Conducting obligatory deeds to be obeyed and implemented

Regarding the notary code of ethics, a notary has a prohibition, such as:

a. Having more than one office, either branch or representative

b. Conduct publicity (promotion), both alone and together.

c. Working closely with other service bureaus / legal entities.

d. Signed the deed whose process of preparing its minut has been prepared by another party. 
e. Sending minuta to client to sign.

f. Trying in any way, so someone moves from another notary to him.

g. Forcing the client by withholding the submitted documents and / or applying psychological pressure with the intention that the client keeps a deed on him.

h. Doing business, either directly or indirectly leading to the emergence of unhealthy competition with fellow notaries.

i. Determine the honorarium to be paid by the client in an amount lower than the fee set by the association.

j. To employ deliberately a person who is still an employee of another notary's office without prior approval from the concerning notary.

k. Disparaging and / or blaming a notary colleague or deed made by him / her.

1. In the event that a notary confronts and / or discovers a deed made by a colleague in which there are serious mistakes and / or compromises the client, the notary public shall notify the concerned colleague of the misconduct he made in a non-patronizing manner, but to prevent the occurrence of things that are not desirable to the client concerned or colleagues.

m. Establish a group of exclusive colleagues with the aim of serving the interests of an agency or institution, moreover closing the possibility for other notaries to participate.

n. Use and include a title that is not in accordance with applicable laws and regulations.

o. Perform other acts commonly referred to as violations of the Notary's Code of Ethics, among others but not limited to offenses against :

1) Conditions in Regulation number 30 of 2004 on Notary Profession.

2) The explanation clause 19 verse (2) Regulation number 30 of 2004 on Notary Profession.

3) The contents of oath of office of notary. 
4) Matters which, in accordance with the provisions of Articles of Incorporation, Bylaws and / or other decisions established by the organization of Indonesian Notary Association may not be performed by members.

\section{Sanction of Code of Ethics}

Sanctions imposed on members who violate the code of conduct may be:

a. Reproof is an attempt to warn a person to be aware of what he has done so that he returns to the right path

b. Warning is advice or almost the same as a reprimand but this can be made in writing.

c. Suspension (Temporary Dismissal) from membership of the association is a sanction given to a person who violates a predefined rule. The penalty is a termination of time.

d. Onzetting of membership of the association.

e. Dismissal with disrespect from membership of the association.

The imposition of sanctions as described above against a member in violation of the Notary's Code of Ethics shall be in accordance with the quantity and quality of the offenses committed by that member.

Notary is not only supervised in his position as a notary, but also supervised as an individual person. This can be clearly known from the chapter50 PJN., mentioned "ignoring the whole of their dignity or making other mistakes, both inside and outside of her position as a notary".

The meaning should not be taken too broadly. Acts that are not public or unknown to the public (the outside world), can not be said to damage the name of the notary in general and the notary in particular. But if the general public knows about the disgraceful deeds and ways of life of the notary, then it could undermine the general public's trust in the notarization and the notary in particular. Against such matters is the need for supervision. 
Thus any act, which is beyond the duties of a notary public, as opposed to the nobility and dignity of a notary's office is included in the supervision referred to in the clause. 50 P.J.N.

Here are some examples of acts contrary to the nobility and dignity of a notary public:

1. To hold a dishonest competition among the notary public;

2. Conduct cooperation in a manner that is not permitted by intermediaries (eg by giving to an intermediary a portion of the honorarium received);

3. Determine a lower honorarium than is generally accepted by the notary (local), with the intention to withdraw to him client-clients from other notaries or to extend the client's sum, at the expense of the other.

\section{E. CLOSING}

\section{Conclusion}

Based on the above discussion, it can be concluded that in carrying out his duties one's profession is a notary which we are currently discussing must cling to the code of ethics to the position of notary. The Code of Ethics is a system of norms, values and rules of professional written, which expressly state what is not true and not good for professionals who are related to the responsibilities of the professionto help executives as professionals in order not to damage professional ethics.

Thus the Notary Code of Conduct is a moral principle determined by the Association of Indonesian Notary Bonds under the Decision of the Congress of the Association and/orwhich is determined and regulated in the laws and regulations governing about it andwhich applies to and shall be obeyed by any and all members of the association and all persons performing duties and positions as notaries.

Sanctions imposed on members who violate the code of ethics may include reprimands, warnings, suspensions (dismissal) of membership 
of the association, onzetting of membership of association, disenchantment of membership of association. The imposition of sanctions as described above against a member in violation of the Notary's Code of Ethics shall be in accordance with the quantity and quality of the offenses committed by that member.

\section{Suggestion}

Based on the above detailed description, it is expected that the notary in running his office will always reflect on the moral ethics of his profession, obey the principle, and submit and obey to every rule governing his positionso that society and all circles can really interpret notary profession as one of noble and dignified profession.

\section{BIBLIOGRAPHY:}

\section{Books:}

Azikin Zainal, 2013, Hukum Dagang (Trade Law), Jakarta: PT Raja Grafindo

Persada.

G.H.S Tobing Lumban, 1983, Peraturan Jabatan Notaris (Notary Office Rules), Jakarta: Erlangga.

Pramudya Kelik dan Ananto Widiatmoko, 2010, Pedoman Etika Profesi Aparat

Hukum (Professional Lawyers Ethics Guidelines), Yogyakarta: Pustaka Yustisia.

Suhrawardi K. Lubis, 2016, Etika Profesi Hukum (Legal Profession Ethics), Jakarta: Sinar Grafika Offset. 